\title{
POTENCY OF BIOCONTROL AGENTS ISOLATED FROM COMPOST AND PEAT SOIL OF TROPICAL PEAT SWAMP FOREST IN KALAMPANGAN ZONE, CENTRAL KALIMANTAN
}

\author{
Yuliar $^{1,2}, Z_{\text {aenal }}$ Abidin $^{3}$ and Wibowo Mangunwardoyo ${ }^{3}$
}

\begin{abstract}
Rhizoctonia solani is a soil pathogen that causes diseases in wide range of hosts of agricultural, horticultural and flower crops. Biological control is the most promising way for the diseases management and it is environment friendly too. The objective of this study was to isolate and screen the potency of soil bacteria as biological control from various local compost and peat soil of tropical peat swamp forest in Kalampangan Zone, Central Kalimantan. Forty seven isolates from peat soil and compost were screened for biocontrol agent of Rhizoctonia solani. Seven out of thirteen peat soil isolates, and six out of thirty three compost isolates showed antagonistic activity against $R$. solani in Potato Dextrose Agar. The cultivation of the antagonistic isolates in Trypticase Soy Broth (TSB) was extracted and analysed by high performance liquid chromatography (HPLC) column. The HPLC analyzes indicated that the antagonistic isolates produce an antifungal iturin A. Macroscopic observation of isolates colonies showed that form of their colonies were amuboid, myceloid, curled, circular, rhizoid, irregular and filamentous. These achievement indicate peat swamp forest not only offer a potential biocontrol agents of damping off but also provide a new source for production of antibiotics.
\end{abstract}

Keywords: Soil bacteria, peat swamp forest, compost, Rhizoctonia solani, iturin A

\section{INTRODUCTION}

Damping off disease not only causes problem on horticultural crop, but also often makes predicament on forest plant nurseries. As reported by Hood et al. (2004), that Milicia regia seedlings had a higher probability of dying due to damping-off disease in low-light conditions characteristic of tropical forest under storey as opposed to higher light conditions that may be found in light gaps. Morever, Lee et al. (2008) stated that damping off caused by Rhizoctonia solani resulted in yield losses in more than 200 crops globally. The use of chemical pesticides is becoming restricted because of concerns for the environment and health. Biological control is therefore a promising strategy for disease management of damping off and it is also environmental friendly.

\footnotetext{
${ }^{1}$ Microbiology Division, Research Center for Biology, The Indonesian Institute of Science, Bogor 16002

${ }^{2}$ Corresponding author: Yrivaie@yahoo.com

${ }^{3}$ Dept. of Biology, Faculty of Mathematics and Natural Sciences, University of Indonesia
} 
Different mechanisms are involved in the interaction between bacteria, used as a biocontrol agents, and fungal plant pathogen, such as a parasitism, cross protection, antibiosis and competition. The antibiotic mechanisms are said to operate when the metabolic products (antibiotics) produced by one species inhibits or suppresses the growth of another species (Shoda, 2000).

The main sources of microbial antibiotics are Streptomyces (Actinomycetes), Bacillus (bacteria) and Penicillium (fungi) (Madigan et al., 1997). These bacteria are used commercially and intensively studied. Bacteria having the ability to form antifungal metabolites can be isolated easily from soil samples. Lievens et al. (1989) and Leyns et al. (1990) found about $30 \%$ of all bacteria isolated from soils were able to produce antifungal inhibition zones in vitro. Soil of peat swamp forest and compost are good samples for searching of bacteria for biocontrol agents. As organic material degrades, composts are able to stimulate bacteria activities (Aryantha et al., 2000). Therefore, compost may contain various genus or species of bacteria; while soil of peat swamp forest that is acidic, may contain acidophilic bacteria. This research will explore the importance of peat swamp forest as source of bacterial control agents of damping off and a new source of peptide antibiotic producer. More specifically, members of the genus Bacillus produce a variety of antifungal peptide antibiotics (Katz and Demain, 1977). Strains of Bacillus subtilis have also been studied as biological control agents of plant pathogens. But, only a few of them were isolated and identified. Indonesia is a mega biodiversity country, and there is a great potential to utilize many antifungal agents especially from genus Bacillus. Increasing concern regarding food safety, environmental pollution and detrimental effects of agrochemical on a variety of nontarget organisms, reducinge the number of approved active pesticide ingredients has generated an interest in biological control agents to prevent and control plant diseases. The strong efficacy of iturin A against various phytopathogenic fungi is similar to the available chemical pesticides. It has been tested for control of a variety of fungi in pure cultures and during composting (Phae et al., 1990). The objective of this study was to isolate and screen the potency of soil bacteria as biocontrol agents from compost and peat soil of tropical peat swamp forest especially Bacillus spp. These bacteria produce antifungals (iturin A). This antibiotic has a strong antifungal activity on large variety of yeast and fungi, but its activity is limited to a few bacteria specially Micrococcus luteus (Besson et al., 1978 as cited in Yuliar, 2002).

\section{MATERIALS AND METHODS}

\section{A. Samples for bacteria isolation}

Samples were used for the isolation of the bacteria are as follows:

1. Peat soils from Kalampangan, Palangkaraya $\left(2^{\circ} 04^{\prime} 51.21^{\prime \prime} \mathrm{S} 114^{\circ} 02^{\prime} 04.18^{\prime \prime} \mathrm{E}\right)$ were collected in different plots (plots number; A1 $(\mathrm{pH}=6.5), \mathrm{E} 6(\mathrm{pH}=6.0), \mathrm{G} 5$ $(\mathrm{pH}=5.4), \mathrm{J} 1(\mathrm{pH}=4.4)$, and J5 $(\mathrm{pH}=3.2)$ (Figure 1). 
2. Various brands of composts (Ratna Cibedug compost (KA), microbiology section, Biology Research Center (KB), Enka Saritani, Bogor (KC), Depok Compost (KD), Sinar Katel Perkasa Bogor (KE) and Anonymous compost (KF).

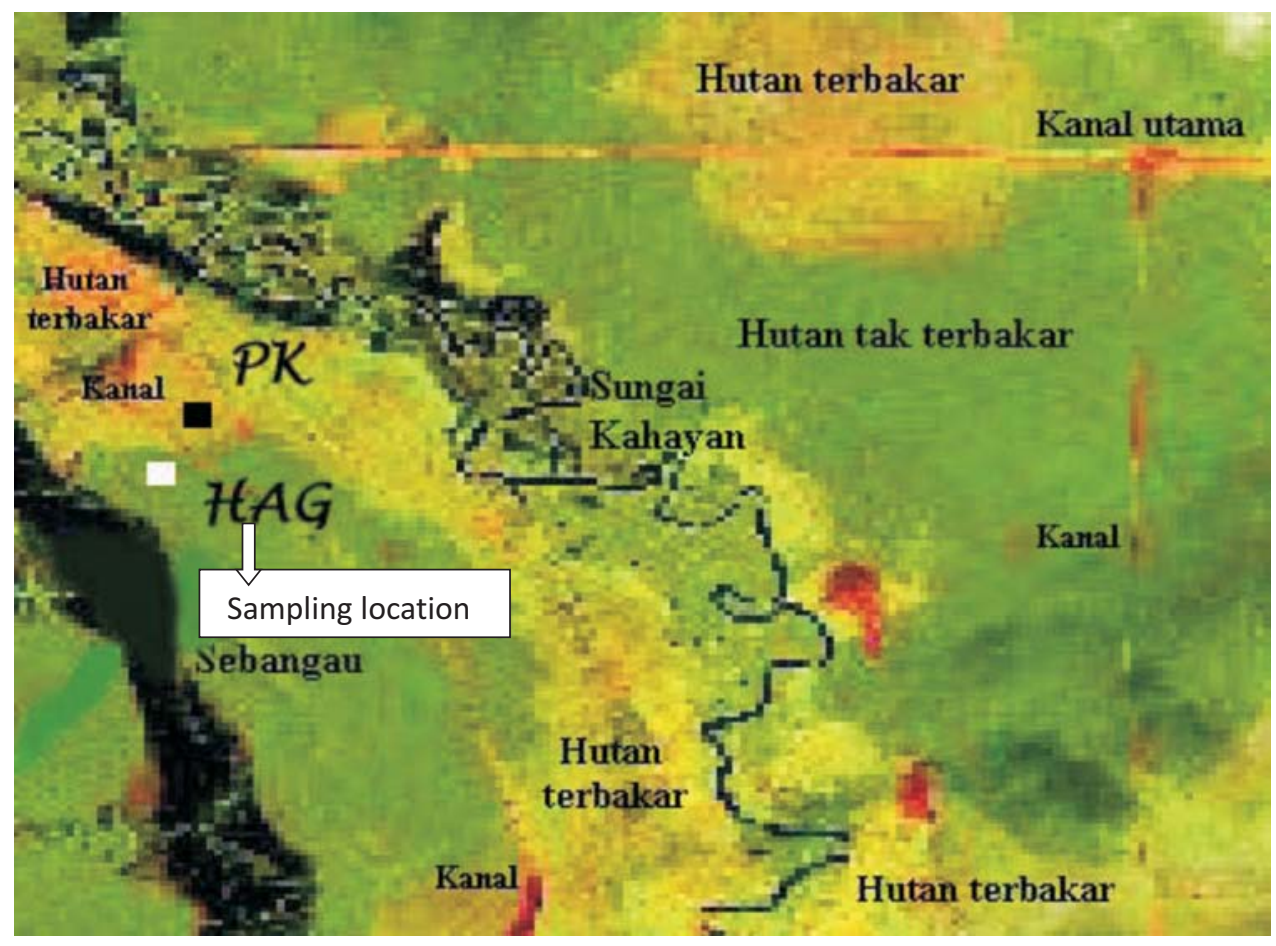

Figure1. Sampling was performed in the forest area around the station JSPS-LIPI

Research cooperation, Kalampangan, Central Kalimantan. This area located between Kahayan and Sebangau river, approximately $40 \mathrm{~km}$ Southeast Palangkaraya (HAG: unburnt natural forest, plots in which sampling has been done, where A1, E6 G5, J1and J5).

\section{B. Bacteria isolation procedure}

Bacteria isolation was carried out by the method described by Steubing (1993). Two grams of each sample (peat soil or compost) were heated at $100^{\circ} \mathrm{C}$ for 15 minutes to kill non-spore-forming mesophilic bacteria. After the heating, the sample was diluted with $2 \mathrm{ml}$ of $0.85 \% \mathrm{NaCl}$ and mixed thoroughly. One hundred $\mu \mathrm{l}$ of $1 / 4000$ dilution sample was spreaded over the sterilized Nutrient Agar (NA) medium on petridish, and incubated at room temperature until day fifth incubation time. 


\section{Purification of bacteria isolates}

A single colony of bacteria was streaked into sterilized NA medium plate. Then, it was incubated for two days (Steubing, 1993).

\section{Precultivation}

Five $\mathrm{mL}$ sterilized LB medium in test tube were inoculated with one loop bacteria isolate. Then, it was incubated in an incubator shaker at $37^{\circ} \mathrm{C}, 124 \mathrm{rpm}$ for about 16 hours (Yuliar, 2002).

\section{E. Cultivation}

Fifty $\mathrm{mL}$ sterilized TSB medium in Erlenmeyer flask were inoculated with $500 \mathrm{dl}$ of pre-cultivated isolate, then it was incubated in the incubator shaker at room temperature for seven days (Yuliar, 2002).

\section{F. Antagonistic test (in vitro test)}

Rhizoctonia solani (sized of $5 \times 5 \mathrm{~mm}$ ) was inoculated onto the center of sterile PDA medium in petridish. After that, four holes in the PDA medium were made using cork borer (the position of four holes were at the same distance from the center of the medium, where the $R$. solani plug was placed). One hundred $\mu$ l of a 7 - day cultivated isolates was put into each hole. For the negative control was distilled water. Finally, the plates were incubated for five days and growth inhibition area was observed (Yuliar, 2002).

\section{G. Extraction and measurement of iturin A}

One $\mathrm{mL}$ of the cultivated isolates for each of these three samples $(\mathrm{KB} 6, \mathrm{KC} 3$ and A13) was transferred to sterile eppendorf $1.5 \mathrm{~mL}$ tube and it was acidified with $2 \mathrm{~N} \mathrm{HCl}$ to $\mathrm{pH}$ around two. After that, the samples were kept overnight at $4^{\circ} \mathrm{C}$ and centrifuged at 4,000 rpm for 15 minutes. Subsequently, the samples were re-suspended and extracted with one $\mathrm{mL}$ methanol for about one $\mathrm{hr}$ at room temperature. Then, the samples were centrifuged at 4,000 rpm for $15 \mathrm{~min}$, and the supernatant was filtered with $0.20 \mu \mathrm{m}$ PTFE membrane filter (Albet-JPT 020, Hahnemuhle company, Barcelona, Spain). Twenty $\mu$ l of the filtrate was injected into HPLC (WATER, WATER cooperation, Milford, USA) and was monitored by the UV detector at $\lambda 205 \mathrm{~nm}$. Condition of HPLC was as follows: Mobile phase; acetonitrile: ammonium acetate (35:65), column C18, flow rate $2 \mathrm{~mL} / \mathrm{min}$.

\section{H. Measurement of cell concentration and $\mathrm{pH}$}

Cell concentration was measured by optical density using a spectrophotometer 
(Perkin Elmer, Perkin Elmer company, Cambridge, USA) at OD $660 \mathrm{~nm} . \mathrm{pH}$ was measured with a $\mathrm{pH}$ meter (Horiba, Horiba Ltd, Kyoto, Japan).

\section{RESULTS AND DISCUSSION}

\section{A. Number of Bacterial Isolates}

Isolations were conducted on 14 bacterial from peat soil and 33 isolates from composts (Table 1). The result showed that soil of peat swamp forest contains less number of bacterial isolates than compost. It was probably because the $\mathrm{pH}$ of soil of peat swamp forest was lower than the compost $\mathrm{pH}$. The $\mathrm{pH}$ range of peat soil samples were 3.2 to 6.5 and compost samples $\mathrm{pH}$ were about 6.8 .

Macroscopic observation showed that the colony of isolates were effuse, low convex, raised and raised with concave beaded edge (Table 2). Edges of the colony form were: verrucose, wave and irregular. A single colony form was; circular, amuboid, myceloid, curled, rhizoid, filamentous and irregular. The colors of colonies were varied from white to yellow.

\section{B. Cell concentration and $\mathrm{pH}$ of isolates cultivation in Tryptic Soy Broth medium}

Isolates $\mathrm{A} 11, \mathrm{~KB} 6$ and $\mathrm{KC} 3$ entered to the end of exponential growth phase on days two and days three of incubation times and the end of stationary phase occurred on days five of incubation time (data not shown). $\mathrm{pH}$ of cultivation medium increased from seven on days three to nine on days five of incubation time (data was not shown). The $\mathrm{pH}$ increased of the medium occurred because the isolates produced the secondary of metabolite compounds namely iturin A (see HPLC analysis). Huang et al. (1993) described the chemical structure of iturin $\mathrm{A}$ is a cyclic peptidolipid, that contains $\mathrm{L}$ amino acids (Asparagine and Glutamine) (Figure 2). These amino acids are bases, so that the $\mathrm{pH}$ of medium increased from seven to nine.

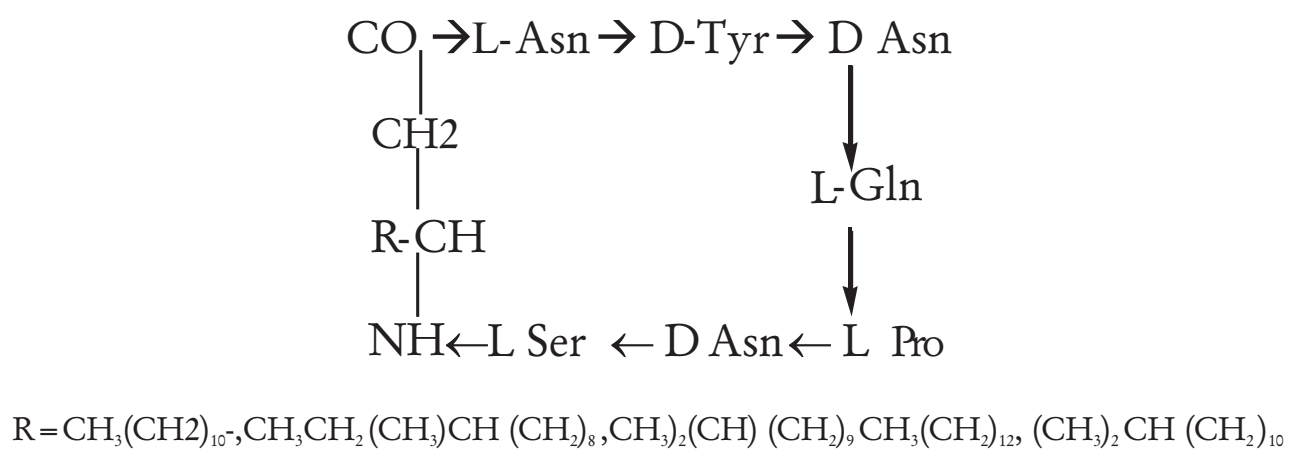

Figure 2. Chemical structure of iturin A 


\section{In vitro test}

In vitro test indicated that a seventh 7-day cultivation time of 13 isolates (A12, A13, $\mathrm{A} 14, \mathrm{~J} 11, \mathrm{~J} 13$, J51, J52, KB2, KB4, KB6, KC2, KC3, and $\mathrm{KC}$ ) inhibited $R$. solani growth (Figure $3 \mathrm{~A}$ ). The ability of the isolate to inhibit $R$. solani, was because the isolates produce an antifungal of iturin A. Iturin A belongs to polypeptide antibiotic that is secreted by Bacillus spp. to the cultivation medium (Shoda, 2000; Yuliar, 2002). Phae et al. (1990) also reported that four isolates (Bacillus spp.) out of 204 isolates inhibited $R$. solani growth. Some others possible inhibition mechanisms of biocontrol agent of the plant diseases in vitro test are chitinase (Huang et al., 2005) and protease production (Olajuyigbe and Ajele, 2005) and siderophore production (de Boer et al., 2003). Mechanisms of biological control agents to antagonize plant pathogens use multiple actions. For instance, Pseudomonas known to produce the antibiotic 2,4diacetylphloroglucinol (DAPG) may also induce host defenses (Lavicoli et al., 2003). Additionally, DAPG producers can aggressively colonize roots, a trait that might further contribute to their ability to suppress pathogen activity in the rhizosphere of wheat through competition for organic nutrients (Raaijmakers and Weller, 2001). There have been many researcher reported a potential use of biocontrol agent microorganisms as an agent stimulating of plant growth (Bottini et al., 2004), fixing nitrogen (Khan and Doty, 2009) and solubilizing phosphate (Malboobi et al., 2009). These reports implied that biocontrol agents not only important for agronomic crops but also applicative and necessary for plant forest. Furthermore application of biocontrol agent A12, A13, A14, J11, J13, J51, J52 to plant of peat swamp forest will get adaptation process easier to environment, because their source are from soil of peat swamp forest. Additionally their application results may be better than with another biocontrol agent that are isolated from other than peat soil. The reason is to achieve an optimal function of them, they should be in optimal growth condition as well as an optimal growth can be reach when they can adapt well to their environment.

\section{Detection of Iturin A}

Iturin A fraction was detected by peaks of retention times of 4.317, 5.642, 5.892 and 9.092 minutes (Figure 4). Yuliar (2002) reported that iturin A fraction of Bacillus subtilis strain RB14-CS has chromatogram peaks pattern with five peaks. This is in an agreement with Phae et al. (1990) and Yu et al. (2002) that detected iturin A with the same peaks pattern. In this experiment, we found only four peaks of the iturin A, with number areas of: 699684, 267647, 365363 and 109323. HPLC analysis was performed on three samples: $\mathrm{KB} 6, \mathrm{KC} 3$ and $\mathrm{A} 13$, their concentration were about $3.7 \mathrm{ppm}$ for $\mathrm{KB} 6$ and $\mathrm{KC} 3$ and $3.1 \mathrm{ppm}$ for $\mathrm{A} 13$ (Figure 5, 6 and 7). The iturin A production of the three isolates was lower than iturin A production by Bacillus subtilis $S 499(140 \mathrm{mg} / \mathrm{l})$ that was reported by Jacques et al. (1999). The highest iturin A production was $3,300 \mathrm{mg} / \mathrm{L}$ that was produced by B. subtilis RB14-CS in soybean meal medium (Yuliar, 2002). The 
lowest of iturin A production by isolate $\mathrm{KB} 6, \mathrm{KC} 3$ and $\mathrm{A} 13$, it was probably because of medium production (TSB) was not a good medium for iturin A production. As Theobald et al. (2000) declared that antibiotic production depend on the medium composition especially on the carbon and nitrogen source and the fermentation condition. Antibiotic production is also dependent on culture condition like temperature, $\mathrm{pH}$, aeration, agitation and cultivation methods. Lynch and Bushell (1995) reported that erythromycin production was significantly enhanced in cyclic feed batch culture compared to batch culture. Furthermore, micro elements also influence the antibiotics production. Wei and $\mathrm{Cu}$ (1998) were successful on enhancement of surfactin productivity by addition of $2-4 \mathrm{mM}$ iron to the medium cultivation. The supplementation of iron to the culture highly improved the production of surfaction as high as $3,500 \mathrm{mg} / \mathrm{L}$ which was almost ten times of the control.

Table 1. Bacteria isolates (Bacillus spp.) from peat soil and composts

\begin{tabular}{|c|c|c|c|c|}
\hline No. & Soil semples & Samples codes & $\mathrm{pH}$ & Isolates codes \\
\hline 1. & Soil peat swamp forest & A1 & 6.5 & A11 \\
\hline 2. & & & & A12 \\
\hline 3. & & & & A13 \\
\hline 4. & & & & A14 \\
\hline 5. & & E6 & 6.0 & E61 \\
\hline 6. & & & & E62 \\
\hline 7. & & G5 & 5.4 & G51 \\
\hline 8. & & & & G52 \\
\hline 9. & & $\mathrm{~J} 1$ & 4.4 & J11 \\
\hline 10. & & & & J12 \\
\hline 11. & & & & $\mathrm{~J} 13$ \\
\hline 12. & & $\mathrm{~J} 5$ & 3.2 & $\mathrm{~J} 51$ \\
\hline 13. & & & & $\mathrm{~J} 52$ \\
\hline 14. & & & & $\mathrm{~J} 53$ \\
\hline 15. & Compost Pondok Ratna Cibedug & KA & 6.8 & KA1 \\
\hline 16. & & & & KA2 \\
\hline 17. & & & & KA3 \\
\hline 18. & $\begin{array}{l}\text { Compost Microbiolo gy, Research } \\
\text { Center Biology, LIPI }\end{array}$ & $\mathrm{KB}$ & 6.8 & KB1 \\
\hline 19. & & & & KB2 \\
\hline 20. & & & & KB3 \\
\hline 21. & & & & KB4 \\
\hline 22. & & & & KB5 \\
\hline 23. & & & & KB6 \\
\hline 24. & & & & KB7 \\
\hline 25. & & & & KB8 \\
\hline
\end{tabular}


Table 1. Continued

\begin{tabular}{|c|c|c|c|c|}
\hline No. & Soil semples & Samples codes & $\mathrm{pH}$ & Isolates codes \\
\hline 26. & Compost Enkasaritani Bogor & $\mathrm{KC}$ & 6.8 & $\mathrm{KC1}$ \\
\hline 27. & & & & $\mathrm{KC} 2$ \\
\hline 28. & & & & $\mathrm{KC} 3$ \\
\hline 29. & & & & $\mathrm{KC} 4$ \\
\hline 30. & & & & KC5 \\
\hline 31. & & & & KC6 \\
\hline 32. & Compost Depok & $\mathrm{KD}$ & 6.8 & KD1 \\
\hline 33. & & & & $\mathrm{KD} 2$ \\
\hline 34. & $\begin{array}{l}\text { Compost Sinar Katel Perkasa } \\
\text { Bogor }\end{array}$ & $\mathrm{KE}$ & 6.8 & KE1 \\
\hline 35. & & & & KE2 \\
\hline 36. & & & & KE3 \\
\hline 37. & & & & KE4 \\
\hline 38. & & & & KE5 \\
\hline 39. & & & & KE6 \\
\hline 40. & Compost Bogor (unlabelled) & $\mathrm{KF}$ & 6.8 & KF1 \\
\hline 41. & & & & $\mathrm{KF} 2$ \\
\hline 42. & & & & KF3 \\
\hline 43. & & & & KF4 \\
\hline 44. & & & & KF5 \\
\hline 45. & & & & KF6 \\
\hline 46. & & & & KF7 \\
\hline 47. & & & & KF8 \\
\hline
\end{tabular}

Table 2. Macroscopic observation of Bacillus spp. colonies

\begin{tabular}{llllll}
\hline Bacillus spp. & Elevationedge & \multicolumn{1}{c}{ Surface } & Form & Colour & \multicolumn{1}{c}{ Codes } \\
\hline A11 & low convex & undulate & irregular & amuboid & cream \\
A12 & low convex & lobate & Irregular & amuboid & cream \\
A13 & low convex & lobate & Irregular & amuboid & cream \\
A14 & effuse & lobate & irregular & amuboid & cream \\
\hline E61 & low convex & erose & smooth & myceloid & cream \\
E62 & low convex & undulate & irregular & myceloid & cream \\
\hline G51 & convex & erose & smooth & circular & light yellow \\
G52 & effuse & lobate & verrucoser & myceloid & white \\
\hline J11 & convex & undulate & undulate & curled & light cream \\
J12 & raised & erose & smooth & myceloid & light cream \\
J13 & effused & entire & smooth & circular & light yellow \\
J51 & low convex & erose & smooth & circular & light cream \\
J52 & raised & lobate & smooth & circular & cream \\
J53 & effuse & crenate & irregular & rhizoid & light yellow \\
\hline
\end{tabular}


Table 2. Continued

\begin{tabular}{|c|c|c|c|c|c|}
\hline Bacillus spp. & Elevationedge & Surface & Form & Colour & Codes \\
\hline $\begin{array}{l}\text { KA1 } \\
\text { KA2 } \\
\text { KA3 }\end{array}$ & $\begin{array}{l}\text { raised } \\
\text { effuse } \\
\text { raised with } \\
\text { concave } \\
\text { beaded edge }\end{array}$ & $\begin{array}{l}\text { undulate } \\
\text { lobate } \\
\text { erose }\end{array}$ & $\begin{array}{l}\text { smooth } \\
\text { smooth } \\
\text { smooth }\end{array}$ & $\begin{array}{l}\text { circular } \\
\text { amuboid } \\
\text { circular }\end{array}$ & $\begin{array}{l}\text { light cream } \\
\text { cream } \\
\text { light yellow }\end{array}$ \\
\hline KB1 & raised & crenate & verrucose & amuboid & cream \\
\hline KB2 & convex & lacerate & undulate & rhizoid & cream \\
\hline KB3 & low convex & undulate & smooth & curled & light brown \\
\hline KB4 & low convex & entire & verrucose & irregular & white \\
\hline KB5 & low convex & undulate & smooth & irregular & light cream \\
\hline KB6 & low convex & entire & smooth & circular & light brown \\
\hline KB7 & low convex & undulate & verrucose & circular & cream \\
\hline KB8 & low convex & entire & verrucose & circular & cream \\
\hline KC1 & effuse & ramose & smooth & rhizoid & cream \\
\hline $\mathrm{KC} 2$ & raised & entire & smooth & circular & light cream \\
\hline $\mathrm{KC} 3$ & low convex & erose & smooth & circular & cream \\
\hline $\mathrm{KC} 4$ & low convex & crenate & smooth & irregular & cream \\
\hline KC 5 & low convex & entire & smooth & circular & cream \\
\hline $\mathrm{KC} 6$ & effuse & lacerate & smooth & myceloid & cream \\
\hline$\overline{\mathrm{KD} 1}$ & effuse & crenate & irregular & amuboid & light cram \\
\hline $\mathrm{KD} 2$ & low convex & lobate & verrucose & rhizoid & light cram \\
\hline KE1 & low convex & crenate & smooth & circular & light cream \\
\hline KE2 & low convex & lobate & verrucose & irregular & cream \\
\hline KE3 & low convex & undulate & smooth & irregular & white \\
\hline KE4 & effuse & erose & smooth & filamentous & white \\
\hline KE5 & raised & entire & smooth & cueled & light cream \\
\hline KE6 & low convex & lobate & smooth & circular & white \\
\hline KF1 & effuse & lobate & smooth & rhizoid & dark cream \\
\hline $\mathrm{KF} 2$ & effuse & entire & irregular & amuboid & cream \\
\hline $\mathrm{KF} 3$ & low convex & entire & smooth & circular & white \\
\hline KF4 & effuse & erose & smooth & amuboid & dark yellow \\
\hline KF5 & effuse & lobate & smooth & amuboid & light cream \\
\hline KF6 & low convex & undulate & undulate & curled & white \\
\hline KF7 & low convex & smooth & smooth & amuboid & light cream \\
\hline KF8 & effuse & smooth & smooth & curled & light cream \\
\hline
\end{tabular}




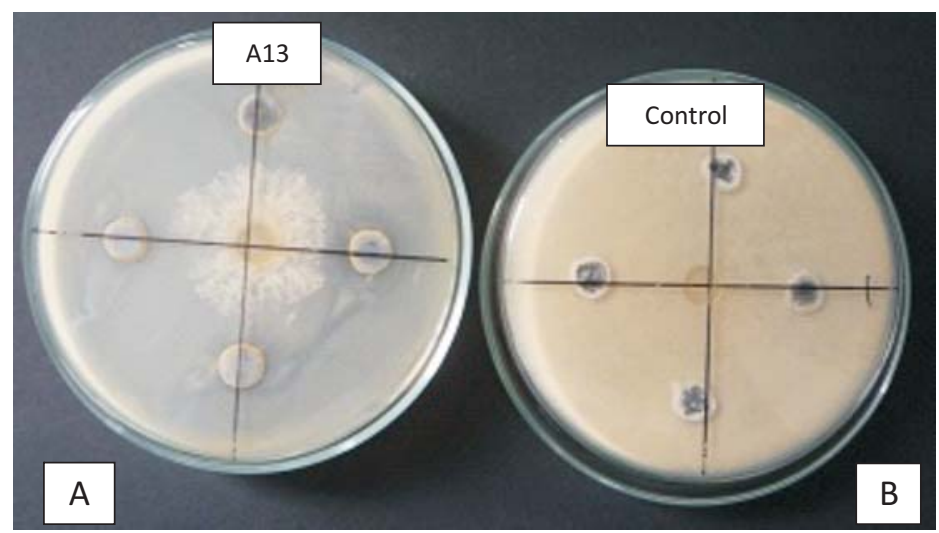

Figure 3. (A) Culture broth of the isolates A13 inhibited Rbizoctonia solani growth, the inhibition area were observed around of the four holes ( $R$. solani mycelia keep away from the holes). (B) Sterilized distilled water as control did not inhibit $R$. solani growth, its mycelia bypass the holes.

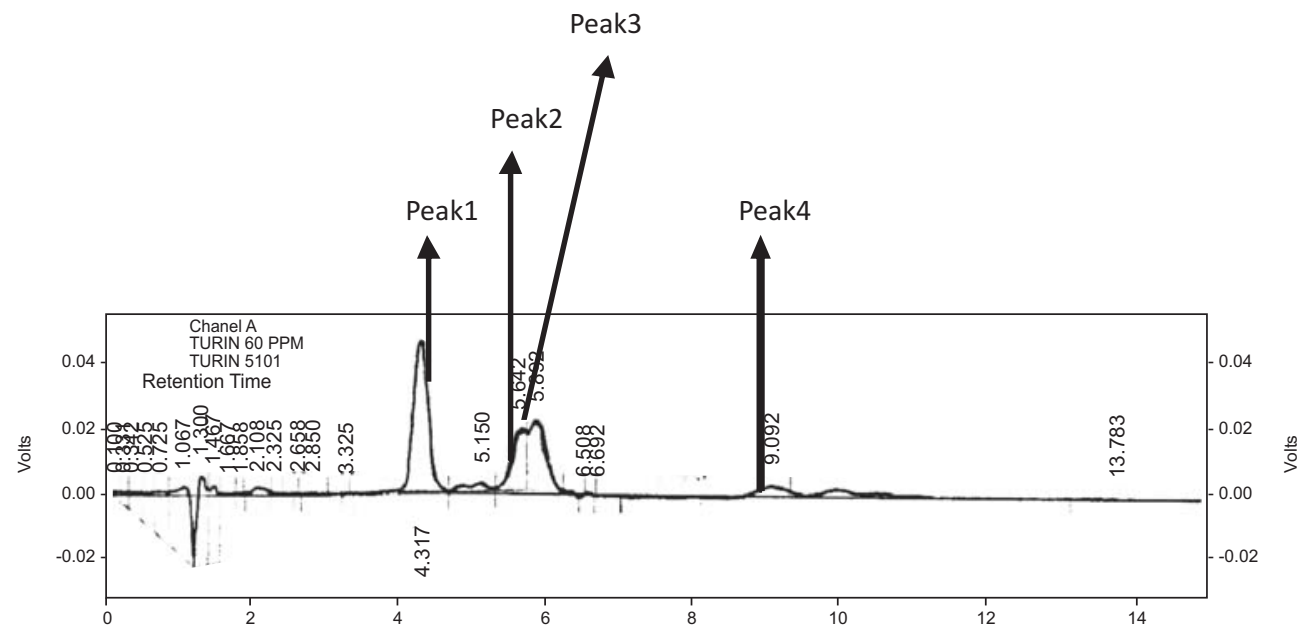

Figure 4. HPLC pattern of iturin A standard (50 ppm), detector A-1 (205 nm) 


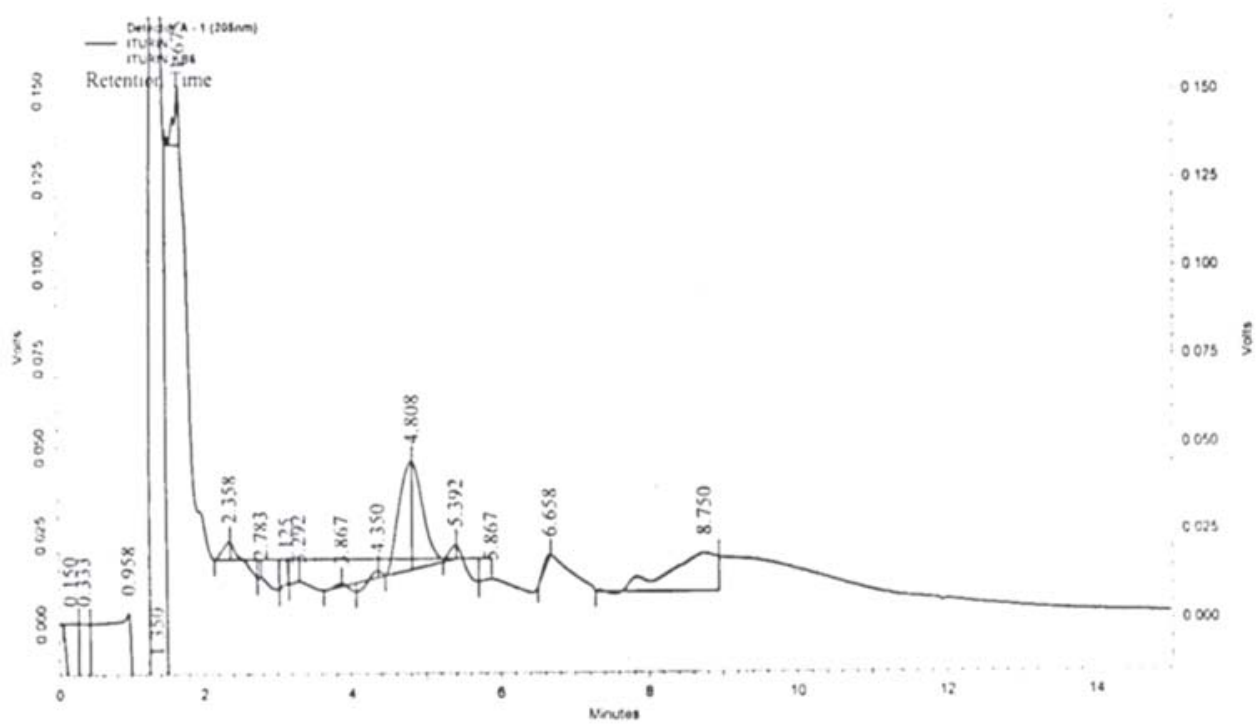

Figure 5. HPLC pattern of iturin A of KB6 isolate,detector A-1 (205 nm)

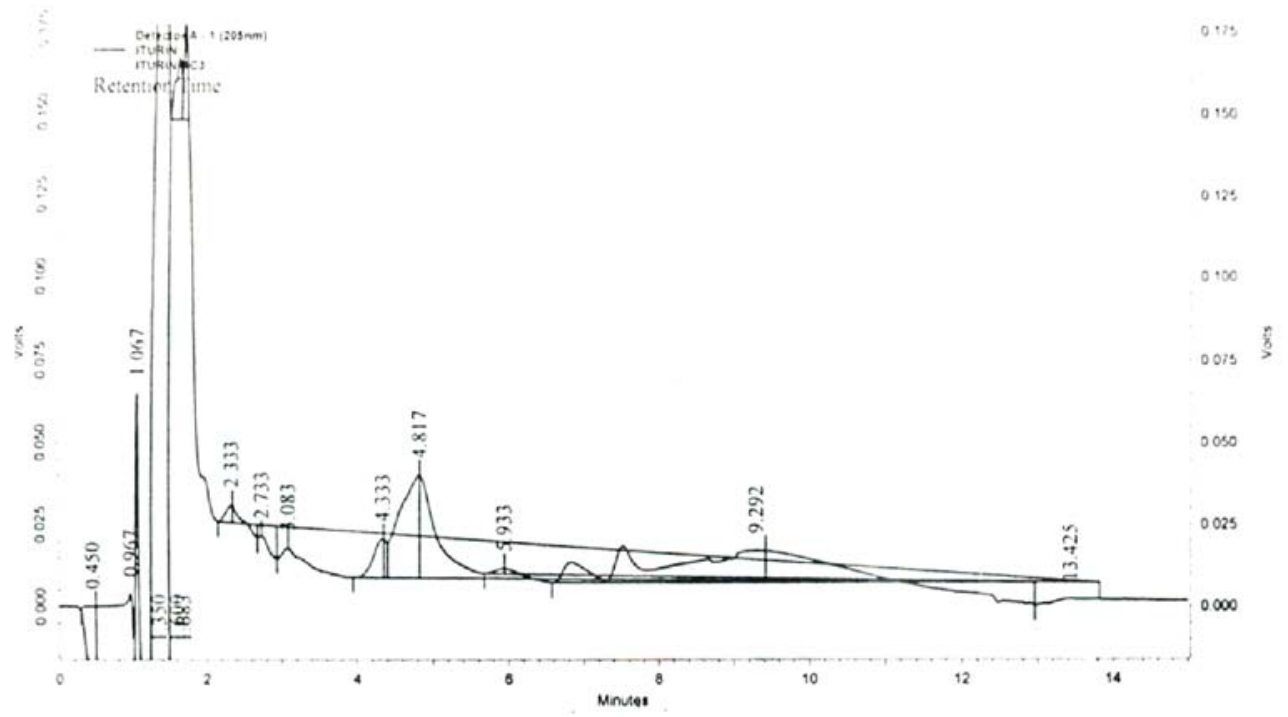

Figure 6. HPLC pattern of iturin A of KC3 isolate, detector A-1 (205 nm) 


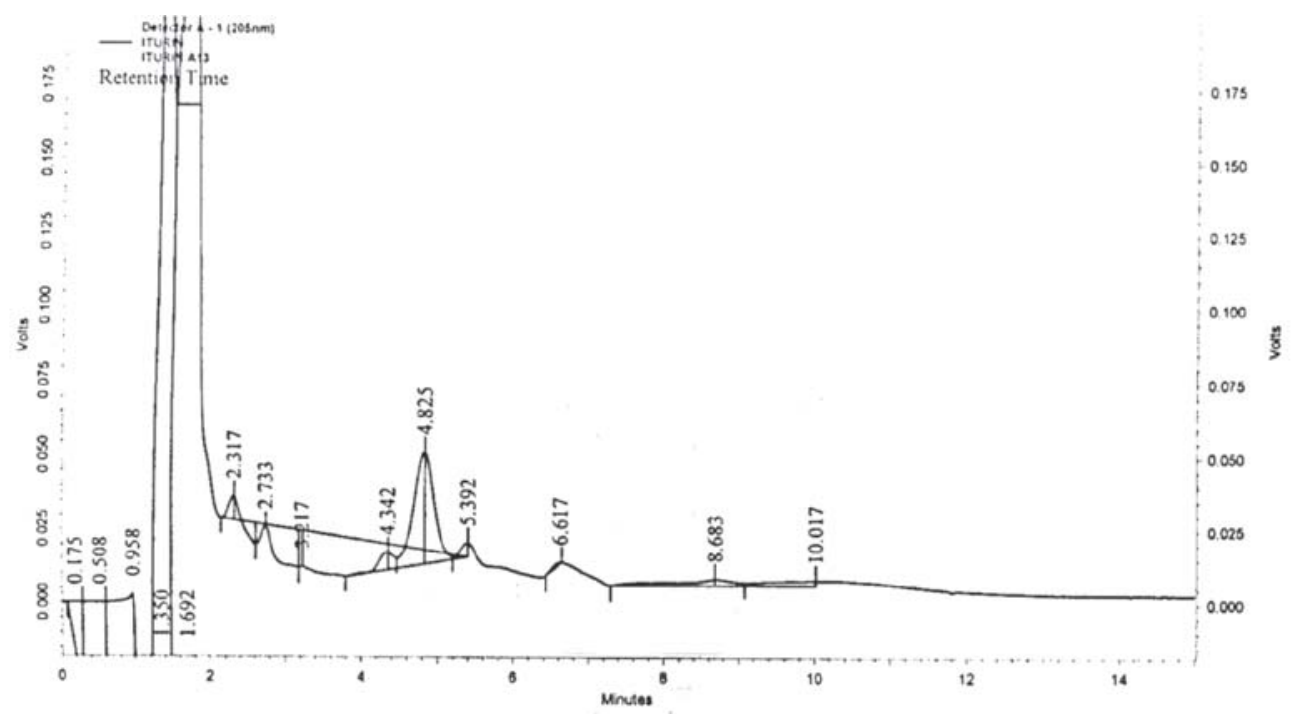

Figure 7. HPLC pattern of iturin A of A13 isolate, detector A-1 (205 nm).

\section{CONCLUSION}

This study shows that seven out of 13 peat soil isolates, and six out of 33 compost isolates showed antagonistic activity against $R$. solani in PDA. Thirteen isolates (A12, $\mathrm{A} 13, \mathrm{~A} 14, \mathrm{~J} 11, \mathrm{~J} 13, \mathrm{~J} 51, \mathrm{~J} 52, \mathrm{~KB} 2, \mathrm{~KB} 4, \mathrm{~KB} 6, \mathrm{KC} 2, \mathrm{KC} 3$, and $\mathrm{KC}$ ) are potential isolates to inhibit $R$. Solani growth. The highest inhibition zone was observed for isolates number KB6, with 32 milliliter the clear zone diameter. The antagonistic isolates produce an antifungal iturin A in TSB medium. It is also need futher research, especially in greenhouse test of the potential isolates to suppress damping off on agricultural crops and plantation forest.

\section{REFERENCES}

Aryantha, I.P., R. Cross and D.I. Guest. 2000. Suppression of Phytophthora cinnamomi in Potting Mixes amended with uncomposted and composted animal manures. Journal of Phytophatology 90(7): 775-782.

Bottini, R., F. Cassan and P. Piccoli. 2004. Gibberellin production by bacteria and its involvement in plant growth promotion and yield increase. Applied Microbiology and Biotechnology 65: 497-503. 
de Boer, M., P. Boom, F. Kindt, Joost, J.B. Keurentjes, I. van der Sluis, L.C. van Loon and P.H.A.M. Baker. 2003. Control Fusarium wilt of radish by combining of Pseudomonas putida strains that have different diseases mechanisms. Phytopatology 93(5): 626-632.

Hood, L.A., M.D. Swaine and P.A. Mason. 2004. The influence of spatial patterns of damping off disease and arbuscular mycorrhizal colonization on tree seedling establishment in Ghanian tropical forest soil. Journal of Ecology 92:816-823.

Huang, C.H., T. Ano and M. Shoda. 1993. Nucleotide sequence and characteristics of the gene, Ipa-14, responsible for biosynthesis of the lipopeptide antibiotics iturin A and surfactin from Bacillus subtilis RB14. Journal of Fermentation and Bioengineering 76: 445-450.

Huang, C.J., T.K. Wang, S.C. Chung and C.Y. Chen. 2005. Identification of an antifungal chitinase from a potential biocontrol agent Bacillus cereus. Journal of Biochemistry and Molecular Biology 38(1): 82-88.

Jacques, P., C. Hbid, J. Destain, H. Razafindralambo, M. Paquot, E.D. Pauw and P. Thonart. 1999. Optimization of biosurfactant lipopeptide production from Bacillus subtilis S499 by Plackett-Burman Design. Applied Biochemistry and Biotechnology 77:223-233.

Katz, E. and A.L. Demain. 1977. The peptide antibiotics of Bacillus: Chemistry, biogenesis, and possible functions. Bacteriological Review 41(2): 449-474.

Khan, Z. and S.L. Doty. 2009. Characterization of bacterial endophytes of sweet potato plants. Plant Soil 322: 197-207.

Lavicoli, A., E. Boutet, A. Buchala and J.P Métraux. 2003. Induced systemic resistance in Arabidopsis thaliana in response to root inoculation with Pseudomonas fluorescens CHAO. Molecular Plant-Microbe Interactions 16: 851-858.

Lee, T.O., Z. Khan, S.G. Kim and Y.H. Kim. 2008. Amendment with peony root bark improves the biocontrol efficacy of Trichoderma harzianum against Rhizoctonia solani. Journal of Microbiology and Biotechnology 18(9): 1537-1543.

Leyns, F., B. Lambert, H. Joos and J. Swings. 1990. Antifungal Bacteria from different Crops. British Library Cataloguing in Publication data. Pp. 437-443.

Lievens, K.H., R. van Rijsbergen, F.R. Leyns, B. Lambert, P. Tenning, J. Swings and H. Joos. 1989. Dominant rhizosphere bacteria as a source for antifungal agents. Pesticide Science 27: 141-154.

Lynch, H.C. and M.E. Bushell. 1995. The physiology of erythromycin biosynthesis in cyclic fed batch culture. Microbiology 141: 3105-3111. 
Madigan, M.T., J.M. Martinko and J. Parker. 1997. Brock biology of microorganisms. 8th ed. Prentice Hall International Inc., New Jersey.

Olajuyigbe, F.M. and J.O. Ajele. 2005. Production dynamics of extracellular protease from Bacillus species. African Journal of Biotechnology 4(8): 776-779.

Malboobi, M.A., P. Owalia, M. Behbahani, E. Sarokhani, S. Moradi, B. Yakhchali, A. Deljou and K.M. Heravi. 2009. Solubilization of organic and in organic phosphates by three highly efficient soil bacteria isolates. Biotechnology 25: 14711477.

Phae, C.G., M. Shoda and H. Kubota. 1990. Suppressing effect of Bacillus subtilis and it's products on phytopathogenic microorganisms. Journal of Fermentation and Bioengineering 69(1): 1-7.

Raaijmakers, J.M., M. Vlami and J.T. De Souza. 2002. Antibiotic production by bacterial biocontrol agents. Antonie van Leeuwenhook 81: 537-547.

Shoda, M. 2000. Bacterial control of plant disease. Journal of Bioscience and Bioengineering 89(6): 515-521.

Steubing, P.M. 1993. Isolation of an unknown bacterium from soil. Proceedings of the 14th Workshop/Conference of the Association for Biology Laboratory Education (ABLE), Las Vegas: 81-114.

Theobald, U., J. Schimana and H. Fiedler. 2000. Microbial growth and production kinetics of Streptomyces antibioticus Tu 6040. Antonie van Leeuwenhook 78: 307313.

Wei, Y. and I. Chu. 1998. Enhancement of surfactin production in iron-enriched media bu Bacillus subtilis ATCC21332. Enzyme Microbial Technology 22: 724-728.

Yu, G.Y., J.B. Sinclair, G.L. Hartman and B.L. Bertagnolli. 2002. Production of iturin A by Bacillus amyloliquefaciens suppressing Rhizoctonia solani. Soil Biology and Biochemistry (34): 955-963.

Yuliar. 2002. Study on medium compositions to enhance iturin A productivity by Bacillus subtilis RB14-CS. Master Thesis. The Graduate School of Tokyo Institute of Technology, Tokyo. 59p. 